\title{
ANALISIS KESESUAIAN WISATA PANTAI BLEBAK SEBAGAI OBYEK REKREASI PANTAI DI KABUPATEN JEPARA JAWA TENGAH
}

\author{
Analysis of Tourism Suitability of the Blebak Beach as a Beach Recreation Object in the Jepara Regency, \\ Central Java
}

\author{
Anggita Yohana Febrilia, Siti Rudiyanti*), Frida Purwanti \\ Program Studi Manajemen Sumberdaya Perairan, Jurusan Perikanan \\ Fakultas Perikanan dan Ilmu Kelautan, Universitas Diponegoro \\ Jl. Prof. Soedharto, SH, Tembalang, Semarang, Jawa Tengah - 50257, Telp/Fax. 085803891913 \\ Email: anggitayohana97@gmail.com
}

\begin{abstract}
ABSTRAK
Pantai Blebak adalah destinasi wisata pantai di Desa Sekuro Kecamatan Mlonggo Kabupaten Jepara yang memiliki peluang untuk dikembangkan akan tetapi terdapat kendala yaitu informasi mengenai pantai ini belum terekspose dengan baik. Tujuan penelitian ini untuk mengetahui potensi wisata, persepsi masyarakat dan pengunjung tentang daya tarik, fasilitas, aksesibilitas dan kepedulian lingkungan; serta menilai kesesuaian wisata Pantai Blebak. Penelitian ini dilakukan pada bulan Maret 2018. Metode yang digunakan dalam penelitian yaitu metode kualitatif dengan membagikan kuesioner kepada 30 responden masyarakat menggunakan teknik purposive sampling, 30 responden pengunjung menggunakan teknik accidental sampling dan metode kuantitatif untuk mengukur kesesuaian wisata Pantai Blebak. Potensi wisata yaitu 1). Potensi Biologi : empat jenis mangrove (Rhizopora mucronata , $R$. apiculata, Avicenia alba, Sonneratia $\mathrm{sp}$ ) dan terdapat satu jenis lamun (Thalassia hemprichii) serta makrofauna (kepiting, gastropoda dan bivalvia); 2.) Potensi Fisik : Atraksi wisata (Pemandangan alam, pasir putih, perairan jernih dan ombak tenang); Aksesibilitas (sejauh $13 \mathrm{~km}$ dari Kota Jepara, kondisi jalan sudah beraspal); Fasilitas (akomodasi penginapan, kurangnya penerangan jalan, tersedianya air bersih dari sumur tanah, hanya terdapat 4 toilet dan 2 mushola; Aktivitas masyarakat dan pengujung berjalan dengan baik 3.) Potensi Budaya : sedekah laut dilaksanakan satu minggu setelah hari raya Idul Fitri. Persepsi responden tentang daya tarik wisata yaitu baik, fasilitas yaitu kurang baik, aksesibilitas dan kepedulian lingkungan yaitu baik. Hasil perhitungan Indeks Kesesuaian Wisata Pantai Blebak yaitu tergolong dalam kategori pantai yang sesuai untuk kegiatan rekreasi pantai
\end{abstract}

Kata Kunci : Indeks Kesesuaian Wisata; Pantai Blebak; Persepsi responden ; Potensi Wisata

\section{ABSTRACT}

Blebak Beach is coastal tourist destinations in the Sekuro Village, Mlonggo Sub-district that has a chance to be developed but there are constraints on information about this beach that has not being well exposed. The purpose of this study were to reveal the potential of tourism, perception of community and visitors about attractivenees, facility, accessibility and environmental awareness; and to assess the tourism suitability of the beach. This research was conducted in March 2018. The methods used in this research was qualitative method by distribute questionnaires to 30 community respondents using purposive sampling technique, 30 visitors respondents using accidental sampling technique and quantitative method to measure the tourism suitability of the beach. Tourism potentials include 1). Biological Potentials: four types of mangrove (Rhizopora mucronata, $R$. apiculata, Avicenia alba, Sonneratia sp) and one type lamun (Thalassia hemprichii), macrofauna (crabs, gastropods and bivalves); 2.) Physical Potentials: Tourist attraction (Natural scenery, white sand, clear waters and calm waves); Accessibility (as far as $13 \mathrm{~km}$ from Jepara City, road conditions have been paved); Facilities (Hotel accommodation, poor lighting, availability of clean water from ground wells, 4 toilets and 2 mushollas, Activity of community and visitors are going well 3.) Cultural Potentials: sea charity which held in a week after Eid Mubarak. Perception of the respondents about attraction are good, facilities are deficient, accessibility and environmental awareness are good. The calculation result of Suitability Index of Blebak Beach is classified into the appropriate category for recreational beach activities.

Keywords : Tourism Suitability Index; Blebak Beach; Perception Respondents; Tourism Potency

*) Penulis Penanggungjawab

${ }^{\circ}$ Copyright by Management of Aquatic Resources (MAQUARES) 


\section{PENDAhUluan}

Wilayah pesisir adalah zona peralihan antara darat dan laut. Secara ekologis, wilayah pesisir memiliki nilai sumberdaya alam yang tinggi karena merupakan wilayah yang paling produktif. Pantai memiliki bentuk dinamis serta dapat berubah karena faktor alam dan faktor non alam. Perubahan faktor alam dapat terjadi karena gelombang, arus dan cuaca sedangkan perubahan faktor non alam terjadi karena aktivitas manusia dalam pemanfaatan sumberdaya pantai secara berlebihan.

Pemanfaatan sumberdaya sebagai kawasan wisata dapat memberikan dampak yang baik bagi masyarakat. Salah satu keuntungan dalam pemanfaatan oleh masyarakat adalah sebagai tempat kegiatan wisata. Wisata pantai adalah suatu kegiatan wisata yang dilakukan dengan tujuan utamanya yaitu untuk rekreasi, olahraga dan melihat pesona alam di pantai tersebut. Pantai yang dijadikan tempat wisata biasanya memiliki daya tarik yang potensial seperti pasir putih dan ombak yang tenang. Kegiatan wisata ini dapat memberikan kontribusi yang besar dalam meningkatan kesejahteraan masyarakat setempat. Sehingga kawasan wisata mampu menampung jumlah wisatawan atau pegunjung tanpa menurunkan kualitas lingkungan pantai.

Pantai Blebak mempunyai peluang dalam upaya pengembangan wisata karena daya tarik yang dimilikinya, akan tetapi terdapat masalah yang menghambat peluang tersebut. Salah satu masalahnya karena hingga saat ini belum terekspose dengan baik dan belum adanya informasi dan hasil penelitian mengenai Indeks Kesesuaian Wisata pantai di lokasi tersebut. Oleh karena itu, penelitian ini dilakukan supaya dapat memberikan informasi mengenai kesesuaian wisata pantai Blebak. Tujuan penelitian ini adalah untuk mengetahui potensi wisata, persepsi responden tentang daya tarik, fasilitas, aksesibilitas dan kepedulian lingkungan serta untuk mengetahui kesesuaian wisata pantai.

\section{MATERI DAN METODE PENELITIAN}

\section{Materi}

Materi yang diamati dalam penelitian ini adalah potensi wisata, persepsi masyarakat dan pengujung tentang daya tarik, fasilitas, aksesibilitas dan kepedulian lingkungan serta mengamati kondisi bio fisik kesesuaian wisata Pantai Blebak. Alat yang digunakan dalam penelitian ini adalah Global Positioning System (GPS) yang digunakan untuk menentukan titik koordinat pengambilan data pada tiga stasiun, rollmeter untuk mengukur lebar pantai, tongkat berskala digunakan untuk mengukur kedalaman perairan dan secchi disk modifikasi digunakan untuk mengukur kecerahan perairan, waterpass modifikasi digunakan untuk mengukur kemiringan pantai, current meter modifikasi untuk mengukur kecepatan arus, stopwatch digunakan untuk menghitung waktu pengukuran, kamera untuk alat dokumentasi penelitian dan alat tulis digunakan untuk mencatat hasil pengukuran.

\section{Metode}

Penelitian ini menggunakan metode penelitian kualitatif untuk persepsi responden masyarakat dan pengunjung di wisata Pantai Blebak. Teknik purposive sampling dengan membagikan 30 kuesioner kepada masyarakat, perhitungan penentuan sampel masyarakat menggunakan metode Slovin dengan derajat kecermatan 20\%. Berikut ini adalah rumus penentuan sampel kuesioner masyarakat (Sugiyono,2011):

$$
\mathrm{n}=\frac{\mathrm{N}}{\mathrm{nd}^{2}+1}
$$

Keterangan :

$\mathrm{n}:$ Jumlah Sampel, N : Jumlah populasi / penduduk, d : Derajat kecermatan.

Kemudian teknik accidental sampling dengan membagikan kuesioner kepada 30 responden pengunjung. Menurut Gumilang (2016) ciri umum penelitian kualitatif yaitu data tidak berbentuk angka, lebih banyak narasi, deskripsi, cerita, dokumentasi tertulis maupun tidak tertulis serta dalam mengolah da menganalisis data metode ini menstrukturkan hubungan antara faktor atau mengklarifikasi hubungan antar faktor. Analisisi kesesuaian wisata pantai Blebak menggunakan metode kuantitatif berdasarkan matriks IKW Yulianda (2007).

\section{Teknik Pengukuran Indeks Kesesuaian Wisata Pantai}

Penelitian ini menggunakan metode purposive sampling dalam penentuan titik sampling lapangan. Pertimbangan dalam menggunakan metode purposive sampling karena teknik pengambilan sampel atau sumber data yang di dapatkan berdasarkan pertimbangan tertentu atau sengaja yang dapat mewakili dari lokasi penelitian.

Pantai Blebak memiliki panjang garis pantai 294 meter dimana dalam menentukan titik sampling dibagi menjadi 3 stasiun yaitu Stasiun 1 : S 06 $30^{\prime} 11.73^{\prime \prime}$ E $110^{\circ} 40^{\prime} 15.50$ ", Stasiun 2 : E 06 $30^{\prime} 11.86^{\prime \prime} \mathrm{S} 110^{\circ} 40^{\prime}$ $17.13^{\prime \prime}$. Stasiun 3 : E $06^{\circ} 30^{\prime} 11.49^{\prime \prime} \mathrm{S} 110^{\circ} 40^{\prime} 19.23^{\prime \prime}$. Jarak antar stasiun selebar 20 meter dengan pertimbangan lokasi tersebut merupakan tempat yang sering dijadikan sebagai rekreasi berenang, kemudian jarak dari garis pantai ke arah laut selebar 15 meter hal ini diperkuat oleh Febyanto et al., (2014) yang menyatakan bahwa jarak 15 meter dari bibir pantai kearah laut ini merupakan daerah yang banyak disukai pengunjung melakukan kegiatan wisata, karena jaraknya yang terjangkau atau masih dekat dengan garis bibir pantai, dengan demikian dapat mewakili informasi yang dibutuhkan oleh peneliti. Peta penelitian tersajikan pada Gambar 1. 


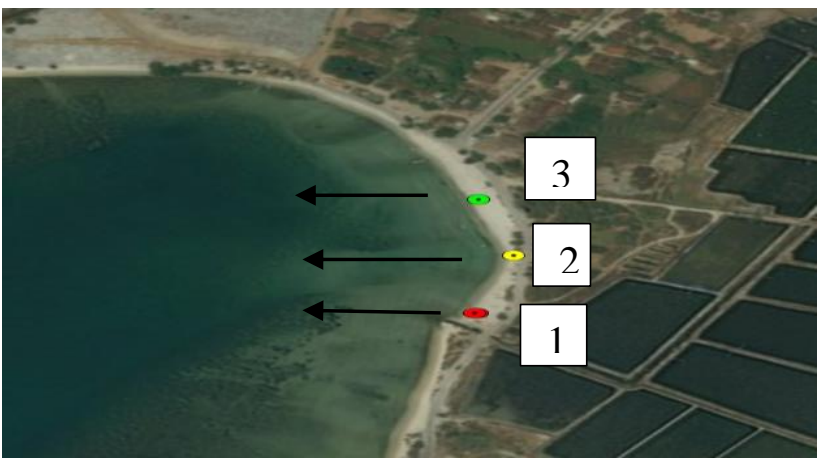

Gambar 1. Penentuan Titik Sampling

Teknik pengukuran parameter kesesuaian wisata pantai Blebak, adalah sebagai berikut:

1. Kedalaman perairan menggunakan tongkat berskala yang dimasukkan ke dalam dasar perairan yang menjadi stasiun pengambilan data, nilai yang ditunjukkan pada tongkat berskala merupakan nilai kedalaman.

2. Penentuan tipe pantai dilakukan secara pengamatan visual, yaitu dengan mengamati jenis substrat dan warna pasirnya (Chasanah et al., 2017)

3. Pengukuran lebar pantai menurut Chasanah et al., (2017) lebar pantai dilakukan menggunakan roll meter, yaitu jarak antara vegetasi terakhir yang ada di pantai dengan batas surut terendah.

4. Material dasar perairan dilakukan dengan cara pengamatan visual di lapangan.

5. Kecepatan Arus diukur menggunakan current meter modifikasi.

Kecepatan arus dapat diketahui menggunakan rumus sebagai berikut:

Kecepatan arus $(\mathrm{V})=(\mathrm{S})$ jarak $(\mathrm{m}) /(\mathrm{t})$ waktu (detik)

6. Kemiringan pantai dapat di ukur dengan tongkat sepanjang 2 meter diletakkan secara horizontal diatas pasir dan diatasnya diletakkan waterpass yang dilekatkan pada batas pantai teratas. Menghitung ketinggian tongkat dengan bantuan Rollmeter kemudian di dapatkan sudut kemiringan pantai dan dimasukan dalam rumus menurut (Panjaitan et al ., 2012):

Keterangan :

$$
\alpha=\arctan \frac{Y}{X}
$$

$\alpha$ : Sudut yang di bentuk; Y : Jarak antara garis tegak lurus yang dibentuk oleh kayu horizontal dengan permukaan pasir dibawahnya; $\mathrm{X}$ : Panjang kayu 2 meter

7. Pengukuran kecerahan perairan dilakukan dengan menarik rollmeter berjarak 15 meter ke arah laut dari garis pantai. Pengukuran kecerahan dilakukan menggunakan secchi disk modifikasi yang diikat dengan tali kemudian diturunkan secara perlahan hingga batas tidak tampak, yakni warna hitam pada secchi disk tidak lagi terlihat lalu di ukur panjangnya. Setelah itu, secara perlahan ditarik secchi disk keatas hingga warna hitam pada secchi disk tersebut kembali terlihat lalu diukur juga berapa panjangnya, ini adalah batas tampak. Untuk lebih jelasnya rumus menghitung kecerahan adalah sebagai berikut:

$$
\text { Kecerahan air }(\mathrm{cm})=\frac{\text { Jarak tidak tampak }(\mathrm{cm})+\operatorname{Jarak} \text { tampak }(\mathrm{cm})}{2}
$$

8. Pengamatan tutupan lahan dilakukan dengan melihat proses pertumbuhan kondisi pantai secara alamiah atau buatan manusia.

9. Pegamatan biota yang berbahaya menurut Chasanah et al., (2017) biota berbahaya merupakan faktor penting dalam wisata baik rekreasi maupun berenang. Semakin sedikit biota berbahaya yang ditemukan maka lokasi tersebut akan semakin baik. Biota yang menjadi indikator adalah bulu babi, ikan pari, ular laut, dan ikan berbisa.

10. Ketersediaan Air Tawar dapat dilakukan dengan pengamatan visual dan juga pengukuran, yaitu dengan mengamati sumber air tawar yang terdekat dari pantai yang digunakan oleh pengelola untuk menjadi sumber air bersih. Kemudian, jarak antara pantai dengan sumber air diukur.

\section{Analisis Data}

Data kuisioner persepsi masyarakat dan pengunjung dinilai menggunakan skala Likert, dimana untuk setiap pilihan jawaban yang diberikan responden diberikan skor atau penilaian yang berguna untuk memberikan gambaran dan mendukung pernyataan. Jawaban yang telah diberikan responden berdasarkan pilihannya akan dijabarkan menjadi indikator yang digunakan sebagai tolok ukur dalam menyusun kesimpulan. Menurut Sugiyono (2013), bahwa skala Likert digunakan untuk mengukur sikap, pendapat dan persepsi seseorang atau sekelompok orang tentang fenomena sosial. 
Data hasil sampling lapangan Indeks Kesesuaian Wisata (IKW) pantai Blebak di analisis berdasarkan matrik IKW menurut Yulianda (2007) dan kemudian rumus IKW (Yulianda,2007) :

Keterangan:

$$
\mathrm{IKW}=\sum\left[\frac{N i}{N \max }\right] \times 100 \%
$$

IKW : Indeks Kesesuaian Wisata (\%)

$N i \quad$ : Nilai parameter ke-i (bobot x skor)

Nmaks : Nilai maksimum dari kategori wisata (84)

Setelah dihitung menggunakan rumus IKW, kemudian dicocokan sesuai kategori yang tertera dibawah ini (Yulianda, 2007) :

S1 : Sangat sesuai dengan nilai $83-100 \%$

S2 : Sesuai dengan nilai $50-<83 \%$

S3 : Sesuai bersyarat dengan nilai $17-<50 \%$

TS : Tidak sesuai $<17 \%$

Definisi dari kelas atau kategori kesesuaian lahan wisata pantai yang terbagi dalam empat kelas kesesuaian adalah sebagai berikut (Yulianda, 2007):

a. Kategori S1 : Sangat Sesuai (Highly Suitable), pada kategori ini tidak memiliki faktor pembatas dalam suatu penggunaan tertentu secara lestari atau hanya memiliki pembatas yang kurang berarti dan tidak berpengaruh secara nyata.

b. Kategori S2 : Sesuai, pada kategori ini memiliki faktor pembatas dalam suatu penggunaan tertentu secara lestari. Faktor pembatas tersebut akan mempengaruhi kepuasan dalam kegiatan wisata dan keuntungan yang diperoleh serta meningkatkan masukan perlakuan yang diperlukan untuk mengusahakan kegiatan wisata tersebut.

c. Kategori S3 : Sesuai Bersyarat, pada kategori ini memiliki faktor pembatas dalam suatu penggunaan tertentu secara lestari atau memiliki pembatas yang berpengaruh lebih nyata. Faktor pembatas ini akan lebih meningkatkan masukan perlakuan yang diperlukan untuk mempertahankan kegiatan wisata.

d. Kategori TS : Tidak Sesuai (Not Suitable), pada kategori ini memiliki faktor pembatas yang permanen, sehingga tidak mungkin untuk mengembangkan kegiatan wisata secara lestari.

\section{HASIL DAN PEMBAHASAN}

\section{Hasil}

Hasil dari penelitian potensi wisata disajikan pada Tabel 1 dibawah ini :

Tabel 1. Potensi Wisata Pantai Blebak

Potensi Variabel Keterangan

\begin{tabular}{ll}
\hline Biologi & Keberadaan flora \\
dan fauna & Flora : terdapat empat jenis mangrove yaitu Rhizopora mucronata, \\
& R. apiculata, Avecenia alba dan Sonneratia sp, dan satu jenis lamun \\
& Thalassia Hemprichi (Zuhaira,2017). \\
& - Fauna : kepiting, bivalvia dan terdapat spesies gastropoda yaitu \\
& Cerithidea cingulata, C. qudrata, Terebralis sulcata, Chicoreus \\
& capucinus, Littoraria scabra, L. melanostoma dan Volema \\
& paradisiaca (Setiyowati,2018).
\end{tabular}

\begin{tabular}{lll}
\hline Fisik & - Atraksi Wisata & - Atraksi Wisata: Pemandangan alam, pasir putih, perairan jernih, \\
& - Aksesibilitas & sunset di sore hari dan ombak tenang (Bapppeda,2017) \\
- Fasilitas & - Aksesibilitas: Lokasi pantai 13 km dari Kabupaten Jepara, kondisi \\
& - Aktivitas & jalan yang beraspal dan belum ada alat transportasi umum dan biro \\
& perjalanan untuk menuju tempat wisata (Bappeda,2017) \\
& - Fasilitas meliputi: Akomodasi penginapan, rumah makan, parkir, \\
& gazebo, tempat duduk, taman bermaian, wahana permainan air, \\
& tersedianya air bersih dari sumur tanah, terdapat toilet dan mushola \\
& (Bapppeda,2017) \\
& - Aktivitas masyarakat dan pengunjung yang terjalin dengan baik. \\
\hline Budaya & - Sedekah laut & Diadakan setiap satu tahun sekali setelah Idul Fitri \\
\hline
\end{tabular}

Hasil dari penelitian persepsi tentang daya tarik wisata Pantai Blebak disajikan pada Tabel 2 dibawah ini : Tabel 2. Persepsi Daya Tarik Wisata di Pantai Blebak

\begin{tabular}{llllll|lcccc}
\hline \multicolumn{1}{c}{ Kategori } & \multicolumn{4}{c|}{ Masyarakat } & \multicolumn{4}{c}{ Pengunjung } \\
\hline \multicolumn{1}{c}{ Daya Tarik } & $\mathbf{1}$ & $\mathbf{2}$ & $\mathbf{3}$ & $\mathbf{4}$ & $\mathbf{5}$ & $\mathbf{1}$ & $\mathbf{2}$ & $\mathbf{3}$ & $\mathbf{4}$ & $\mathbf{5}$ \\
\hline Pemandangan alam & 0 & 2 & 6 & 20 & 2 & 0 & 2 & 9 & 17 & 2 \\
Pasir pantai & 0 & 1 & 4 & 21 & 4 & 0 & 1 & 14 & 13 \\
\hline
\end{tabular}




\begin{tabular}{lccccc|ccccc}
\hline Rekreasi berenang & 0 & 4 & 13 & 12 & 1 & 1 & 6 & 13 & 8 & 2 \\
Wahana permainan air & 2 & 9 & 9 & 10 & 0 & 1 & 6 & 9 & 12 & 2 \\
Pohon mangrove & 4 & 2 & 5 & 19 & 0 & 2 & 6 & 11 & 11 & 0 \\
Kuliner & 0 & 4 & 17 & 8 & 1 & 0 & 4 & 12 & 14 & 0 \\
Ombak & 0 & 1 & 10 & 19 & 0 & 2 & 1 & 10 & 16 & 1 \\
\hline Jumlah & 6 & 23 & 64 & $\mathbf{1 0 9}$ & 8 & 6 & 26 & 78 & $\mathbf{9 1}$ & 9 \\
\hline Presentase (\%) & 3 & 11 & 30 & $\mathbf{5 2}$ & 4 & 3 & 12 & 37 & $\mathbf{4 3}$ & 5 \\
\hline
\end{tabular}

NB : 5 : Sangat menarik / Sangat baik; 4: Menarik / Baik; 3 : Cukup menarik / Cukup baik; 2 : Kurang menarik / Kurang baik; 1: Tidak Menarik / Tidak baik.

Berdasarkan penelitian kategori persepsi responden tentang daya tarik didapatkan presentase $52 \%$ (Baik) dan $43 \%$ (Baik).

Hasil dari penelitian persepsi tentang fasilitas wisata Pantai Blebak disajikan pada Tabel 3 dibawah ini :

Tabel 3. Persepsi Fasilitas di Wisata Pantai Blebak

\begin{tabular}{lccccc|ccccc}
\hline \multicolumn{1}{c}{ Kategori } & \multicolumn{5}{c}{ Masyarakat } & \multicolumn{5}{c}{ Pengunjung } \\
\hline \multicolumn{1}{c}{ Fasilitas } & $\mathbf{1}$ & $\mathbf{2}$ & $\mathbf{3}$ & $\mathbf{4}$ & $\mathbf{5}$ & $\mathbf{1}$ & $\mathbf{2}$ & $\mathbf{3}$ & $\mathbf{4}$ & $\mathbf{5}$ \\
\hline Tempat area parkir & 3 & 22 & 3 & 2 & 0 & 2 & 8 & 11 & 8 & 1 \\
Toilet umum & 0 & 17 & 10 & 3 & 0 & 1 & 13 & 11 & 4 & 1 \\
Mushola & 0 & 9 & 11 & 4 & 6 & 1 & 12 & 8 & 7 & 2 \\
Tempat duduk & 0 & 3 & 9 & 18 & 0 & 0 & 1 & 15 & 11 & 3 \\
Warung makan & 0 & 2 & 12 & 15 & 1 & 0 & 4 & 15 & 10 & 1 \\
Penginapan & 5 & 9 & 5 & 9 & 2 & 6 & 10 & 4 & 10 & 0 \\
Tempat sampah & 3 & 15 & 7 & 4 & 0 & 6 & 17 & 7 & 0 & 0 \\
\hline Jumlah & 11 & $\mathbf{7 7}$ & 57 & 54 & 8 & 12 & 65 & $\mathbf{7 1}$ & 50 & 8 \\
\hline Presentase (\%) & 5 & $\mathbf{3 7}$ & 28 & 26 & 4 & 6 & 31 & $\mathbf{3 4}$ & 25 & 4 \\
\hline
\end{tabular}

NB : 5 : Sangat menarik / Sangat baik; 4: Menarik / Baik; 3 : Cukup menarik / Cukup baik; 2 : Kurang menarik / Kurang baik; 1: Tidak Menarik / Tidak baik.

Berdasarkan penelitian kategori persepsi responden tentang fasilitas didapatkan presentase $37 \%$ (Kurang Baik) dan $34 \%$ (Cukup Baik).

Hasil dari penelitian persepsi tentang aksesibilitas di wisata Pantai Blebak disajikan pada Tabel 4 dibawah ini :

Tabel 4. Persepsi Aksesibilitas di Wisata Pantai Blebak

\begin{tabular}{lccccc|ccccc}
\hline \multicolumn{1}{c}{ Kategori } & \multicolumn{4}{c|}{ Masyarakat } & \multicolumn{5}{c}{ Pengunjung } \\
\hline \multicolumn{1}{c}{ Aksesibilitas } & $\mathbf{1}$ & $\mathbf{2}$ & $\mathbf{3}$ & $\mathbf{4}$ & $\mathbf{5}$ & $\mathbf{1}$ & $\mathbf{2}$ & $\mathbf{3}$ & $\mathbf{4}$ & $\mathbf{5}$ \\
\hline Jalan Menuju Pantai & 2 & 4 & 9 & 15 & 0 & 2 & 16 & 10 & 2 & 0 \\
Rute Jalan & 0 & 2 & 12 & 15 & 1 & 1 & 4 & 19 & 6 & 0 \\
Transportasi Umum & 7 & 15 & 8 & 0 & 0 & 7 & 14 & 5 & 4 & 0 \\
Petunjuk Arah Tempat & 0 & 12 & 9 & 7 & 2 & 1 & 10 & 9 & 9 & 1 \\
Lokasi & & & & & & & & & & \\
Jarak Menuju Pantai & 0 & 3 & 9 & 18 & 0 & 2 & 4 & 14 & 10 & 0 \\
Rambu Lalu Lintas & 0 & 2 & 6 & 17 & 5 & 2 & 8 & 11 & 6 & 0 \\
\hline Jumlah & 11 & 38 & 53 & $\mathbf{7 2}$ & 8 & 15 & 56 & $\mathbf{6 8}$ & 37 & 1 \\
\hline Presentase (\%) & 6 & 21 & 29 & $\mathbf{4 0}$ & 4 & 9 & 31 & $\mathbf{3 8}$ & 21 & 1 \\
\hline
\end{tabular}

NB : 5 : Sangat menarik / Sangat baik; 4: Menarik / Baik; 3 : Cukup menarik / Cukup baik; 2 : Kurang menarik / Kurang baik; 1: Tidak Menarik / Tidak baik.

Berdasarkan penelitian kategori persepsi responden tentang aksesibilitas didapatkan presentase $40 \%$ (Baik) dan $38 \%$ (Cukup Baik).

Hasil dari penelitian persepsi tentang kepedulian lingkungan di wisata Pantai Blebak disajikan pada Tabel 5 dibawah ini

Tabel 5. Persepsi Kepedulian Lingkungan di Wisata Pantai Blebak

\begin{tabular}{|c|c|c|c|c|c|c|c|c|c|c|}
\hline Kategori & \multicolumn{5}{|c|}{ Masyarakat } & \multicolumn{5}{|c|}{ Pengunjung } \\
\hline $\begin{array}{l}\text { Kepedulian } \\
\text { Lingkungan }\end{array}$ & 1 & 2 & 3 & 4 & 5 & 1 & 2 & $\mathbf{3}$ & 4 & 5 \\
\hline Keberadaan sampah & 5 & 9 & 6 & 10 & 0 & 3 & 11 & 8 & 8 & 0 \\
\hline Sanksi buang sampah & 5 & 12 & 8 & 5 & 0 & 7 & 14 & 2 & 6 & 1 \\
\hline $\begin{array}{l}\text { Kegiatan ramah } \\
\text { lingkungan }\end{array}$ & 2 & 2 & 7 & 17 & 2 & 2 & 6 & 12 & 9 & 1 \\
\hline
\end{tabular}




\begin{tabular}{lllllllllll}
\hline Jumlah & 12 & 23 & 21 & $\mathbf{3 2}$ & 2 & 12 & $\mathbf{3 1}$ & 22 & 23 & 2 \\
\hline Presentase (\%) & 13 & 26 & 23 & $\mathbf{3 6}$ & 2 & 13 & $\mathbf{3 4}$ & 25 & 26 & 2 \\
\hline
\end{tabular}

NB : 5 : Sangat menarik / Sangat baik; 4: Menarik / Baik; 3 : Cukup menarik / Cukup baik; 2 : Kurang menarik / Kurang baik; 1: Tidak Menarik / Tidak baik.

Berdasarkan penelitian kategori persepsi responden tentang aksesibilitas didapatkan presentase $36 \%$ (Baik) dan $34 \%$ (Kurang Baik).

Hasil dari nilai Indeks Kesesuaian wisata di Pantai Blebak disajikan pada Tabel 6 dibawah in : Tabel 6. Kesesuaian Wisata Pantai Blebak Kategori Rekreasi

\begin{tabular}{|c|c|c|c|c|c|c|c|c|c|c|c|c|}
\hline \multirow[t]{2}{*}{ Parameter } & \multicolumn{4}{|c|}{ Stasiun 1} & \multicolumn{4}{|c|}{ Stasiun 2} & \multicolumn{4}{|c|}{ Stasiun 3} \\
\hline & Bobot & Hasil & Skor & $\mathrm{Ni}$ & Bobot & Hasil & Skor & $\mathbf{N i}$ & Bobot & Hasil & Skor & $\mathrm{Ni}$ \\
\hline Kedalaman (m) & 5 & 0,77 & 3 & 15 & 5 & 0,74 & 3 & 15 & 5 & 0,76 & 3 & 15 \\
\hline Tipe Pantai & 5 & $\begin{array}{l}\text { Pasir } \\
\text { putih }\end{array}$ & 3 & 15 & 5 & $\begin{array}{l}\text { Pasir putih } \\
\text { sedikit } \\
\text { karang }\end{array}$ & 2 & 10 & 5 & $\begin{array}{c}\text { Pasir } \\
\text { putih } \\
\text { sedikit } \\
\text { karang }\end{array}$ & 2 & 10 \\
\hline $\begin{array}{l}\text { Lebar Pantai } \\
\text { (m) }\end{array}$ & 5 & 4,3 & 1 & 5 & 5 & 4,9 & 1 & 5 & 5 & 7,5 & 1 & 5 \\
\hline $\begin{array}{l}\text { Material Dasar } \\
\text { Perairan }\end{array}$ & 3 & Pasir & 3 & 9 & 3 & $\begin{array}{l}\text { Karang } \\
\text { berpasir }\end{array}$ & 2 & 6 & 3 & $\begin{array}{l}\text { Karang } \\
\text { berpasir }\end{array}$ & 2 & 6 \\
\hline $\begin{array}{l}\text { Kecepatan } \\
\text { Arus }\end{array}$ & 3 & 0,05 & 3 & 9 & 3 & 0,04 & 3 & 9 & 3 & 0,06 & 3 & 9 \\
\hline $\begin{array}{l}\text { Kemiringan } \\
\text { Pantai }\left(\left(^{\circ}\right)\right.\end{array}$ & 3 & 7,4 & 3 & 9 & 3 & 3,4 & 3 & 9 & 3 & 6,6 & 3 & 9 \\
\hline Kecerahan (\%) & 1 & 100 & 3 & 3 & 1 & 100 & 3 & 3 & 1 & 100 & 3 & 3 \\
\hline $\begin{array}{l}\text { Penutupan } \\
\text { Lahan }\end{array}$ & 1 & $\begin{array}{c}\text { Lahan } \\
\text { terbuka, } \\
\text { cemara }\end{array}$ & 3 & 3 & 1 & $\begin{array}{c}\text { Lahan } \\
\text { terbuka, } \\
\text { pandan laut }\end{array}$ & 3 & 3 & 1 & $\begin{array}{c}\text { Lahan } \\
\text { terbuka, } \\
\text { cemara }\end{array}$ & 3 & 3 \\
\hline $\begin{array}{l}\text { Biota } \\
\text { Berbahaya }\end{array}$ & 1 & Tidak ada & 3 & 3 & 1 & Tidak ada & 3 & 3 & 1 & Tidak ada & 3 & 3 \\
\hline $\begin{array}{l}\text { Ketersediaan } \\
\text { air Tawar }(\mathrm{km})\end{array}$ & 1 & 0,07 & 3 & 3 & 1 & 0,05 & 3 & 3 & 1 & 0,03 & 3 & 3 \\
\hline Total Skor & & & & 74 & & & & 66 & & & & 66 \\
\hline IKW (\%) & & & & 3(S1) & & & & $8(\mathrm{~S} 2)$ & & & & $8(\mathrm{~S} 2$ \\
\hline
\end{tabular}

NB: S1 : Sangat Sesuai; S2 : Sesuai; S3 : Sesuai Bersyarat

\section{Pembahasan}

\section{Potensi Wisata Pantai Blebak}

Berdasarkan penelitian yang telah dilakukan bahwa potensi wisata yang ada di Pantai Blebak yaitu :

1. Potensi biologi (flora dan fauna)

Berdasarkan (Zuhaira, 2017), Pantai Blebak memiliki potensi biologi (flora) dengan 4 jenis mangrove yaitu Rhizopora mucronata, $R$. apiculata, Avicenia alba, Sonneratia $s p$ dan satu jenis lamun Thalassia Hemprichi. Kemudian kebedaan fauna yaitu kepiting, bivalvia dan terdapat spesies gastropoda yaitu Cerithidea cingulata, C. qudrata, Terebralis sulcata, Chicoreus capucinus, Littoraria scabra, L. melanostoma dan Volema paradisiaca (Setiyowati,2018).

2. Potensi fisik (atraksi, aksesibilitas, fasilitas dan aktivitas) meliputi:

a. Atraksi Wisata

Atraksi wisata adalah adalah suatu yang adapat menarik perhatian atau daya tarik. Atraksi yang terdapat di Pantai Blebak adalah atraksi wisata yang bersifat alam.

Adapun atraksi tersebut meliputi :

- Panorama indanya pemandangan pantai, pemandangan pantai yang indah dapat dijadikan sebagai area fotografi.

- Pesisir pantai berupa pasir berwarna putih sedikit kecoklatan yang sangat digemari wisatawan untuk melakukan kegiatan wisata pada waktu luang seperti bermain pasir. 
- Pantai dengan perairan yang jernih dibandingkan dengan pantai-pantai lain yang terdapat di Kecamatan Mlonggo.

- Hamparan tananman mangrove di bagian timur pantai yang dapat menambah keindahan pantai.

- Pemandangan Sunset di sore hari.

- Ombak pantai yang tenang sehingga wisatawan yang ingin melakukan kegiatan berenang tidak perlu merasa khawatir karena dengan ombak yang tenang wisatawan akan merasa tenang dan nyaman.

b. Aksesibilitas

Aksesibilitas merupakan suatu unsur yang sangat penting bagi suatu kawasan wisata untuk mempermudah jangkauan wisatawan. Aksesibilitas dapat berupa sarana transportasi dan fasilitas selama dalam perjalanan. Berikut ini adalah deskripsi aksesibilitas di pantai Blebak :

- Lokasi pantai

Wisata pantai Blebak terletak di dukuh Blebak desa Sekuro kecamatan Mlonggo berjarak $13 \mathrm{~km}$ dari kabupaten Jepara.

- Kondisi sarana dan prasaranan jalan

Kondisi sarana dan prasarana jalan menuju pantai blebak dari masuk gapura sampai ke tempat wisata sudah beraspal akan tetapi tidak semua jalanya dalam kondisi baik. Jarak dari jalan raya menuju pantai yaitu $\pm 2 \mathrm{~km}$.

- Sarana transportasi

Sarana trasportasi menuju pantai Blebak saat ini belum terakomodasi dengan baik karena sampai saat ini belum ada alat transportasi umum untuk menuju pantai, sehingga wisatawan yang datang ke tempat wisata harus menggunakan trasportasi milik pribadi.

c. Fasilitas

Fasilitas adalah suatu unsur terpenting di dalam suatu tempat wisata yang dapat memberikan kemudahan dan kenyamanan bagi wisatawan pantai Blebak. Adapun fasilitas yang ada di pantai Blebak adalah :

- Akomodasi

Akomodasi yang dapat diberikan pada wisatawan pantai Blebak yaitu penginapan (Sekuro Village Beach Resort Jepara) yang berada di pinggir Pantai Blebak dan baru diresmikan pada tahun 2018. Fasilitas yang diberikan oleh penginapan ini yaitu suit room sebanyak 28 kamar, junior suit room 2 kamar, family suit room 1 kamar dan resident villa 5 kamar dan juga dapat menggunakan kolam renang dengan bebas. Pantai Blebak juga menyediakan tempat kuliner yang dapat memberikan kemudahan dan kenyamanan bagi wisatawan pantai Blebak, sehingga wisatawan tidak perlu repot keluar dari kawasan.

- Penerangan

Penerangan yang ada di kawasan pantai Blebak kurang memadai karena kalau malam hari jalan menuju pantai masih gelap.

- Air bersih

Tersedianya sudah air bersih dari sumur tanah yang dapat mempermudah wisatawan apabila membersihkan diri setelah melakukan aktivitas berenang.

- Toilet dan tempat ibadah

Jumlah toilet dan tempat ibadah yang ada di kawasan wisata kurang memadahi karena hanya terdapat 4

d. Aktivitas toilet dan 2 mushola, wisatawan dipungut biaya 2000.

- Masyarakat atau penduduk

Masyarakat merupakan unsur terpenting dalam mendukung industri pariwisata di pantai Blebak. Peran masyarakat dalam kegiatan pariwisata yaitu melayani dan memperlakukan dengan baik wisatawan yang datang ke pantai Blebak. Adapun aktivitas masyarakat :

$>$ Sebagai pekerja tambak udang vanamei

$>$ Sebagai nelayan

$>$ Berdagang di sepanjang pantai

$>$ Petani bersawah

- Wisatawan

Aktivitas yang dilakukan wisatawan selama di pantai Blebak adalah :

$>$ Berenang di pantai

$>$ Melihat aktivitas nelayan mencari ikan

$>$ Menikmati kuliner yang tersedia di pantai Blebak

$>$ Menikmati panorama alam

$>$ Mengabadikan momen selama berwisata

3. Potensi budaya

Potensi budaya yang terdapat di Pantai Blebak yaitu setiap satu tahun sekali satu minggu setelah Idul Fitri masyarakat mengadakan sedekah laut. Tujuan dilakukanya sedekah laut yaitu bentuk rasa syukur masyarakat atas rejeki yang mereka dapatkan dari kawasan wisata pantai. 


\section{Persepsi Responden tentang Daya Tarik}

Daya tarik utama yang dimiliki oleh Pantai Blebak yaitu pantai yang bersih dengan serpihan-serpihan karang, air jernih dan ombak yang sangat tenang. Pengunjung dapat datang ke tempat wisata ini kapan saja dengan harga tiket masuk Rp. 3000 yang ditarik pada hari Sabtu dan Minggu saja. Wisatawan paling banyak saat berekreasi di Pantai Blebak yaitu pada waktu hari libur, kebanyakan dari mereka datang ke pantai ini pada sore hari. Pantai ini tergolong pantai yang sangat teduh dengan angin yang sepoy-sepoy sehingga wisatawan yang berekreasi disana merasa nyaman.

Berdasarkan penelitian yang telah dilakukan didapatkan hasil bahwa persepsi masyarakat tentang daya tarik yang meliputi : pemandangan alam, pasir pantai, rekreasi berenang, wahana permainan air, pohon mangrove, kuliner dan ombak yaitu baik dengan presentase $52 \%$ dan persepsi pengunjung memiliki presentase $43 \%$. Penilaian kurang baik diberikan responden untuk variabel rekreasi pantai karena fasilitas yang tidak lengkap, wahana permainan yang kurang menarik dengan jumlah yang sedikit dan kawasan mangrove yang kurang mendapatkan perhatian dari pengelola pantai sehingga mangrove tidak tertata dengan baik.

\section{Persepsi Responden tentang Fasilitas}

Sejak bulan Agustus 2014 Pantai Blebak sudah melakukan penambahan fasilitas seperti tersedianya tempat bilas, toilet, mushola, gazebo atau tempat duduk dan warung makan sehingga dapat menambah kenyaman dan merasa sangat betah apabila berkunjung ke tempat wisata ini. Berdasarkan hasil penelitian bahwa persepsi kurang baik masyarakat tentang fasilitas yang meliputi tempat area parkir, toilet umum, mushola, tempat duduk, warung makan, penginapan dan tempat sampah memiliki presentase $37 \%$ sedangkan persepsi pengunjung cukup baik dengan presentasi $34 \%$. Mayoritas persepsi masyarakat dan pengunjung memberikan peniliaian kurang baik untuk kondisi area parkir karena lahan area parkir yang sempit sehingga kendaraan tidak tertata rapi, jumlah toilet umum yang hanya terdiri 4 unit dan mushola yang hanya terdiri dari 2 unit serta jumlah tempat sampah yang kurang serta jaraknya yang jauh mengakibatkan kebersihan lingkungan wisata terlihat kurang baik.

\section{Persepsi Responden tentang Aksesibilitas}

Bentuk kemudahan untuk mencapai lokasi tujuan wisata sangat di butuhkan bagi wisatwan untuk meningkatkan minat berkunjung. Hal ini dibuktikan untuk mencapai Pantai Blebak hanya berjarak $13 \mathrm{~km}$ dari kota Jepara dan dari jalan raya kurang lebih $2 \mathrm{~km}$. Hal ini diperkuat oleh Murvianti dan Arida (2015) yang menyatakan bahwa aksesibilitas adalah suatu bentuk kemudahan transportasi menuju pantai yang sangat berpengaruh terhadap minat dan motivasi wistawan untuk berkunjung, karena semakin mudah tingkat aksesibiltas suatu kawasan wisata maka semakiun besar pula minat wistawan untuk berwisata.

Persepsi masyarakat tentang aksesibilitas yaitu baik dengan presentase $40 \%$ sedangkan pengunjung yaitu cukup baik dengan presentase 38\%. Meskipun hasil keseluruhan penilaian masyarakat dan pengunjung bernilai positif, akan tetapi untuk variabel jalan menuju pantai, tranportasi umum dan petunjuk arah ke lokasi wisata mendapatakan penilaian yang kurang baik dari masyarakat maupun pengunjung. Hal tersebut dikarenakan kondisi jalan sudah berlubang dan tidak adanya transportasi umum yang dapat mengantarkan wistawan menuju tujuan wisata serta jumlah petunjuk jalan yang hanya terdapat 2 petunjuk jalan.

\section{Persepsi Responden tentang Kepedulian Lingkungan}

Kepedulian lingkungan adalah suatu usaha yang dilakukan oleh seseorang untuk tidak merusak dan menjaga lingkungan sekitar, dalam hal pengelolaan sampah di Pantai Blebak cukup berjalan dengan baik karena setiap hari petugas sampah atau masyarakat yang berperan dalam pengelolaan sampah selalu membersihkan sampah. Pengelolaan sampah di Pantai Blebak ini membutuhkan biaya yang didapatkan dari hasil penjualan tiket masuk dan dari penarikan biaya kepada penjual yang ada di Pantai Blebak. Persepsi masyarakat tentang kepedulian lingkungan yang meliputi tiga variabel yaitu keberadaan sampah, sanksi buang sampah dan kegiatan ramah lingkungan. Persepsi baik diberikan masyarakat dengan presentase 36\% sedangkan persepsi pengunjung kurang baik dengan presentase $34 \%$. Pemberian penilaian kurang baik dari pengujung ini disebabkan oleh kondisi lingkungan pantai yang banyak dengan sampah berserakan, hal tersebut dipengaruhi oleh jumlah tempat sampah yang sedikit dan jaraknya jauh-jauh dan juga kurang baiknya teguran bagi orang yang membuang sampah sembarangan. Faktor lain yang menyebabkan jumlah sampah di Pantai Blebak menjadi banyak adalah faktor alam karena saat musim penghujan yang mengakibatkan gelombang air laut naik ke daratan dengan membawa banyak sampah.

\section{Kesesuaian Wisata Pantai Blebak \\ Kedalaman}

Hasil pengukuran parameter kedalaman pantai Blebak kategori rekreasi berkisar $0.74 \mathrm{~m}-0.77 \mathrm{~m}$ disetiap stasiun . Berdasarkan matrik kesesuaian wisata hasil tersebut tergolong sangat sesuai, kedalaman yang paling baik untuk kegiatan berenang berada pada kisaran $0-5 \mathrm{~m}$. Menurut Nugraha et al., (2013) bahwa perairan ini merupakan lokasi yang paling ideal untuk melakukan kegiatan rekreasi karena para pengunjung dapat bermain 
air dengan aman. Hasil pengukuran di lapangan menunjukkan bahwa pantai Blebak berdasarkan kedalaman sangat sesuai untuk dijadikan wisata rekreasi dan berenang.

\section{Tipe Pantai}

Tipe pantai di Pantai Blebak adalah dalam kategori sesuai karena pada stasuin 1 pasir putih dan pada stasiun 2 dan 3 yaitu pasir putih sedikit berkarang. Meskipun di stasiun 1 dan 2 terdapat sedikit karang, tetapi serpihan karang tersebut tidak mengganggu aktivitas wisatawan, karena tidak memberikan rasa sakit apabila wistawan menginjaknya. Tipe pantai berpasir stasiun 1 ini sangat sesuai untuk kegiatan wisata daripada tipe pantai yang berlumpur. Hal ini diperkuat oleh Saputra dan Khodijah (2014) yang menyatakan bahwa lokasi yang ideal untuk kegiatan wisata seperti berjemur, berolahraga melihat pemandangan dan bermain pasir pantai yaitu tipe pantai yang berpasir sehingga pengunjung menjadi nyaman dan aman.

\section{Lebar Pantai}

Lebar pantai yang luas akan mempengaruhi dalam kegiatan wisata dan akan membuat wisatawan leluasa untuk bermain di sepanjang pantai. Akan tetapi, lebar pantai di Pantai Blebak di setiap stasiun berkisar antara 4.3 $\mathrm{m}-7.5 \mathrm{~m}$ hasil tersebut menunjukan sesuai tetapi bersyarat.

\section{Material Dasar Perairan}

Material dasar perairan di stasiun 1 yaitu pasir dengan kategori sangat sesuai sedangkan di stasiun 2 dan 3 yaitu karang berpasir hasil tersebut menunjukan bahwa tempat wisata ini sesuai untuk kegiatan wisata. Meskipun di stasiun 2 dan 3 material dasarnya karang berpasir, akan tetapi apabila wisatawan melakukan aktivitas bermain air dan berenang tidak menimbulkan rasa sakit karena serpihan karangnya tidak tajam.

\section{Kecepatan Arus}

Kecepatan arus di Pantai Blebak tergolong lambat berkisar antara $0.04 \mathrm{~m} / \mathrm{s}-0.06 \mathrm{~m} / \mathrm{s}$ di setiap stasiun. Hasil tersebut menunjukan bahwa daerah tersebut sesuai untuk kegiatan wisata. Sari dan Usman (2012) mengemukakan bahwa penggolongan kecepatan arus terdiri atas 4 kategori yaitu kategori arus lambat dengan kecepatan pada kisaran $0-0.25 \mathrm{~m} / \mathrm{s}$, kategori arus sedang dengan kecepatan pada kisaran $0.25-0.50 \mathrm{~m} / \mathrm{s}$, kategori arus cepat dengan kecepatan pada kisaran $0.5-1 \mathrm{~m} / \mathrm{s}$ dan kategori arus sangat cepat dengan kecepatan diatas 1 $\mathrm{m} / \mathrm{s}$.

\section{Kemiringan Pantai}

Kemiringan pantai berkaitan dengan berbagai aktivitas yang dapat dilakukan di pantai. Pengunjung sebagian besar menyukai pantai yang landai karena lebih mudah untuk melakukan berbagai aktivitas. Hasil pengukuran kemiringan pantai di Pantai Blebak berkisar antara $3.4^{\circ}-7.4^{\circ}$ dimana hasil tesebut tergolong sangat sesuai untuk peruntuknya serta memberikan keamanan dan kenyamanan bagi wisatawan yang berwisata karena pantai ini termasuk pantai datar yang kurang dari $10^{\circ}$. Hal tersebut diperkuat oleh Nugraha et al., (2013) yang menyatak bahwa kemiringan pantai yang landai memiliki nilai kemiringan pantai kurang dari $10^{\circ}$. Dengan kondisi seperti itu wajar jika mempunyai nilai kesesuaian yang tinggi apabila dijadikan menjadi wisata rekreasii pantai.

\section{Kecerahan}

Kecerahan perairan di Pantai Blebak setiap stasiun mendapatkan hasil yang sama yaitu $100 \%$ dapat terlihat sampai di dasar perairan atau nilai kecerahan sama dengan nilai kedalaman. Hasil tersebut dapat terjadi karena perairan di tempat wisata Pantai Blebak tergolong jenih daripada pantai - pantai lain yang ada di Kecamatan Mlonggo.

\section{Penutupan Lahan}

Penutupan lahan di Pantai Blebak di tutupi oleh pandan laut dan cemara laut, sehingga dapat membuat lokasi menjadi teduh dan menambah keindahan pantai. Hal ini diperkuat oleh Hendyanto et., al (2014) yang menyatakan bahwa apabila suatu pantai terdapat tumbuhan seperti cemara laut dapat menambah keindahan panorama alam. Sehingga kondisi seperti ini dapat dikatakan sangat sesuai untuk kegiatan wisata pantai seperti rekreasi pantai di Pantai Blebak.

\section{Biota Berbahaya}

Pantai Blebak tidak terdapat biota berbahaya di setiap stasiun, sehingga wisatwan yang datang ke sana tidak perlu merasa khawatir apabila ingin berenang di pantai ini. Sehingga dapat disimpulkan untuk kategori rekreasi pantai ini sangat sesuai untuk kegiatan wisata. Hal ini diperkuat oleh Hendyanto et al., (2014) biota berbahaya merupakan faktor yang dipertimbangkan oleh wisatawan dalam melakukan kegiatan wisata pantai.

\section{Ketersedian Air Tawar}

${ }^{\odot}$ Copyright by Management of Aquatic Resources (MAQUARES) 
Jarak ketersediaan air tawar di Pantai Blebak berkisar antara $0.03 \mathrm{~km}-0.07 \mathrm{~km}$ sehingga dapat disimpulkan bahwa ketersedian air tawar antara lokasi wisata sangat sesuai dengan matrik IKW kategori wisata. Hal ini diperkuat oleh Handayawati et al., (2010) yang menyatakan bahwa saat melakukan kegiatan wisata, ketersediaan air tawar atau bersih sangat dibutuhkan untuk menunjang fasilitas pengelolaan dan pelayanan wisata, hal tersebut juga menjadi kriteria penilaian terhadap kelayakan pengembangan suatu kawasan wisata.

\section{KESIMPULAN DAN SARAN \\ Kesimpulan}

Berdasarkan penelitian yang dilakukan dapat disimpulkan bahwa Pantai Blebak memiliki beberapa potensi yang dapat dikembangkan sebagai obyek daya tarik wisata pantai, yaitu pantai yang memiliki 4 jenis mangrove (Rhizopora mucronata, $R$. apiculata, Avicenia alba, Sonneratia sp, dan terdapat satu jenis lamun (Thalassia hemprichi). Fasilitas yang sudah cukup memadai bagi wisatawan yang berkunjung. Kondisi aksesibilitas yang cukup baik dan akomodasi berupa penginapan sudah tersedia serta adanya sedekah laut yang dilakukan setelah satu minggu Idul Fitri. Persepsi responden tentang daya tarik wisata yaitu baik, fasilitas kurang baik, aksesibilitas dan kepedulian lingkungan yaitu baik. Pantai Blebak memiliki kriteria kesesuaian dengan kategori sesuai untuk dijadikan sebagai obyek rekreasi wisata pantai.

\section{UCAPAN TERIMAKASIH}

Penulis mengucapkan terimakasih kepada Prof. Dr. Ir. Djoko Suprapto, DEA dan Ir. Suryanti, M.Pi selaku dosen penguji yang telah memberikan kritik, masukkan dan saran dalam perbaikan penyusunan skripsi.

\section{DAFTAR PUSTAKA}

Bappeda. 2017. Laporan Akhir Kajian Identifikasi Moda Transportasi bagi Pengembangan Wisata di Jepara. Jepara.

Chasanah, I., P. W. Purnomo dan Haeruddin. 2017. Analisis Kesesuaian Wisata Pantai Jodo Desa Sidorejo Kecamatan Gringsing Kabupaten Batang. Jurnal Pengelolaan Sumberdaya Alam dan Lingkungan., 7 (3) : 235-24.

Febyanto, F., I. Pratikto dan Koesoemadji. 2014. Analisis Kesesuaian Wisata Pantai di Pantai Krakal Kabupaten Gunungkidul. Jurnal of Marine Research., 3(4) : 429-438.

Gumilang, G. S. 2016. Metode Penelitian Kualitatif dalam Bidang Bimbingan Konseling. Jurnal Fokus Konseling., 2(2) : 144-159.

Handayawati, H. S., Budiono dan Soemarno. 2010. Potensi Wisata Alam Pantai-Bahari. Progam Magister Pengelolaan Sumberdaya Lingkungan dan Pembangunan Progam Pascasarjana Universitas Brawijaya, 17 hlm.

Hendyanto, R., C. A. Suryono dan I. Pratikto. 2014. Analisis Kesesuaian Wisata Pantai di Teluk Lombok Kabupaten Kutai Timur Kalimantan Timur. Journal of Marine Research, 2(3) : 211-215.

Murvianti, S. D dan N. S. Arida. 2015. Potensi Pantai Perancak sebagai Daya Tarik Wisata Desa Tebubeneng Kuta Utara Badung. Jurnal Destinasi Pariwisata, 3(2) : 1-7.

Nugraha, H., A. Indarjo dan M. Helmi. 2013. Studi Kesesuaian dan Daya Dukung Kawasan untuk Rekreasi Pantai di Pantai Panjang Kota Bengkulu. Journal of Marine Research., 2(2) : 130-139.

Panjaitan, R. A., Iskandar dan S. Alisyahbana. 2012. Hubungan Perubahan Garis Pantaiterhadap Habitat Bertelur Penyu Hijau (Chelonia mydas) di Pantai Pengumbahan Ujung Genteng Kabupaten Sukabumi. Jurnal Perikanan dan Kelautan., 3(3) : 311-320.

Saputra, B. D dan Khodijah. 2014. Kesesuaian Perairan Kawal Sebagai Kawasan Wisata Pantai di Kabupaten Bintan. Jurnal UMRAH., 1-13.

Sari, T. E dan Usman. 2012. Studi Parameter Fisika dan Kimia Daerah Penangkapan Ikan Perairan Selat Asam Kabupaten Kepulauan Meranti ,Propinsi Riau. Jurnal Perikanan dan Kelautan., 17(1) : 88-100.

Setiyowati, D. 2018. Kelimpahan dan Pola Sebaran Gastropoda di Pantai Blebak. Aquatic Sciences Journal., 5(1) : 8-13.

Sugiyono. 2011. Metode Penelitian Pendidikan Pendekatan Kuantitatif, Kualitatif dan R \& D. Alfabeta, Bandung

${ }^{\circledR}$ Copyright by Management of Aquatic Resources (MAQUARES) 
2013. Metode Penelitian Pendidikan Pendekatan Kuantitatif, Kualitatif dan R \& D. Cetakan ke-19. Alfabeta, Bandung.

Yulianda, F. 2007. Ekowisata sebagai Alternatif Pemanfaatan Sumberdaya Pesisir Berbasis Konservasi. Fakultas Perikanan dan Ilmu Kelautan Institut Pertanian Bogor. Bogor.

Zuhaira, H. 2017. Laporan Parkatikum Ekologi Laut. Departemen Oceanografi, FPIK, Universitas Diponegoro, Semarang. 